\title{
Miocene precipitation in Europe: Temporal trends and spatial gradients
}

\author{
Madelaine Böhme ${ }^{\mathrm{a}, *}$, Michael Winklhofer ${ }^{\mathrm{b}}$, August Ilg ${ }^{\mathrm{c}}$ \\ a Institute for Geoscience, Eberhard Karls University, Tübingen 72076, Germany \\ ${ }^{\mathrm{b}}$ Geo-Bio-Centre ${ }^{L M U}$, Department of Earth and Environmental Science, Ludwig-Maximillians University, Munich 80333, Germany \\ c Schumannstrasse 83, Düsseldorf 40237, Germany
}

\section{A R T I C L E I N F O}

\section{Article history:}

Received 23 December 2009

Received in revised form 29 September 2010

Accepted 30 September 2010

Available online 8 October 2010

\section{Keywords}

Miocene

Precipitation

Climate gradient

Turnover event

\begin{abstract}
A B S T R A C T
It is known from present-day climates that both temporal and spatial variations in precipitation can be more pronounced than those in temperature and thus influence ecosystems and human society in more substantial way. However, very little is known about such variations in the past. Here we present an analysis of 206 palaeoprecipitation data from two twelve million year long proxy records of precipitation for Southwest (Calatayud-Teruel basin) and Central Europe (Western and Central Paratethys), spanning the late Early and Middle to Late Miocene (17.8-5.3 Ma) at a temporal resolution of about $80 \mathrm{kyr}$ and $200 \mathrm{kyr}$, respectively. The estimates of precipitation are based on the ecophysiological structure of herpetological assemblages. The results show that precipitation variations in both regions have large amplitudes during the Miocene with comparable temporal trends at longer time scales. With locally $300 \mathrm{~mm}$ up to more than $1000 \mathrm{~mm}$ more rainfall per year than present, the early Langhian and the Tortonian were relatively wet periods, whereas the late Langhian and late Serravallian were relatively dry, with up to 300 to $500 \mathrm{~mm}$ less precipitation than present. The most humid time intervals were the early and middle Tortonian washouse climate periods. Overall, our data suggest that the latitudinal precipitation gradient in Europe from the Middle to Late Miocene were highly variable, with a general tendency towards a reduced gradient relative to present day values. The gradient decreases during cooling periods and increases during warming periods, similar to results from simulations of future climate change. Interestingly, the precipitation gradient was reversed during the second washhouse climate period and the Early Messinian, which may have causes a negative hydrologic balance in the Eastern Paratethys during the latter time. Yet, our reconstructed gradient curve shows no direct correlation with the global temperature signal from oxygen isotopes, which implies a non-linear regional response. Our results further suggest that major fluctuations in the precipitation gradient can be responsible for shifts in ecosystem distribution, and particularly, for faunal turnover in South Western Europe.
\end{abstract}

(C) 2010 Elsevier B.V. All rights reserved.

\section{Introduction}

In present-day climates both temporal and spatial variations in precipitation can be significant, with substantial influence on ecosystems and human societies. Coupled atmosphere-ocean climate models have shown that small-scale global temperature variations can substantially alter the global precipitation budget and especially the regional distribution of rainfall. For instance, all future global warming scenarios predict global precipitation to increase between $1.4 \%$ and $2.3 \%$ per one degree of warming (Meehl et al., 2007), which can be attributed to a higher water-holding capacity of the atmosphere at elevated temperatures (Douville et al., 2002). However, regional variations in precipitation change can vary significantly. A multi-model analysis for future climate change projects a strong

\footnotetext{
* Corresponding author. Tel.: + 49 8921805544; fax: + 498921806602. E-mail address: m.boehme@ifg.uni-tuebingen.de (M. Böhme).
}

decrease in precipitation in lower to middle latitudes and a significant increase in higher latitudes and along the equator (Fig. 1). For continental Europe, models for the next century (Christensen et al., 2007: Fig. 11.5) predict annual precipitation to drop by $30 \%$ in the south and to rise by up to $20 \%$ in the north, which would strongly amplify the existing meridional precipitation gradient over Europe. Even if the magnitude of future rainfall anomalies remain unclear due to uncertainties in model formulations and future anthropogenic emissions (Rowell and Jones, 2006), the strong coupling between variations of temperature and precipitation is evident.

To understand the regional response of precipitation to global temperature change in the past, it is necessary to develop a proxybased palaeo-precipitation database. It is clear that the approach relies on good temperature estimates too. The global temperature record reconstructed from marine proxy data is well constrained. However, the temperature resolution of terrestrial proxy-based palaeotemperature estimates is usually not finer than $1^{\circ} \mathrm{C}$, and as a consequence, small-scale temperature variations in the past can easily be overlooked. 


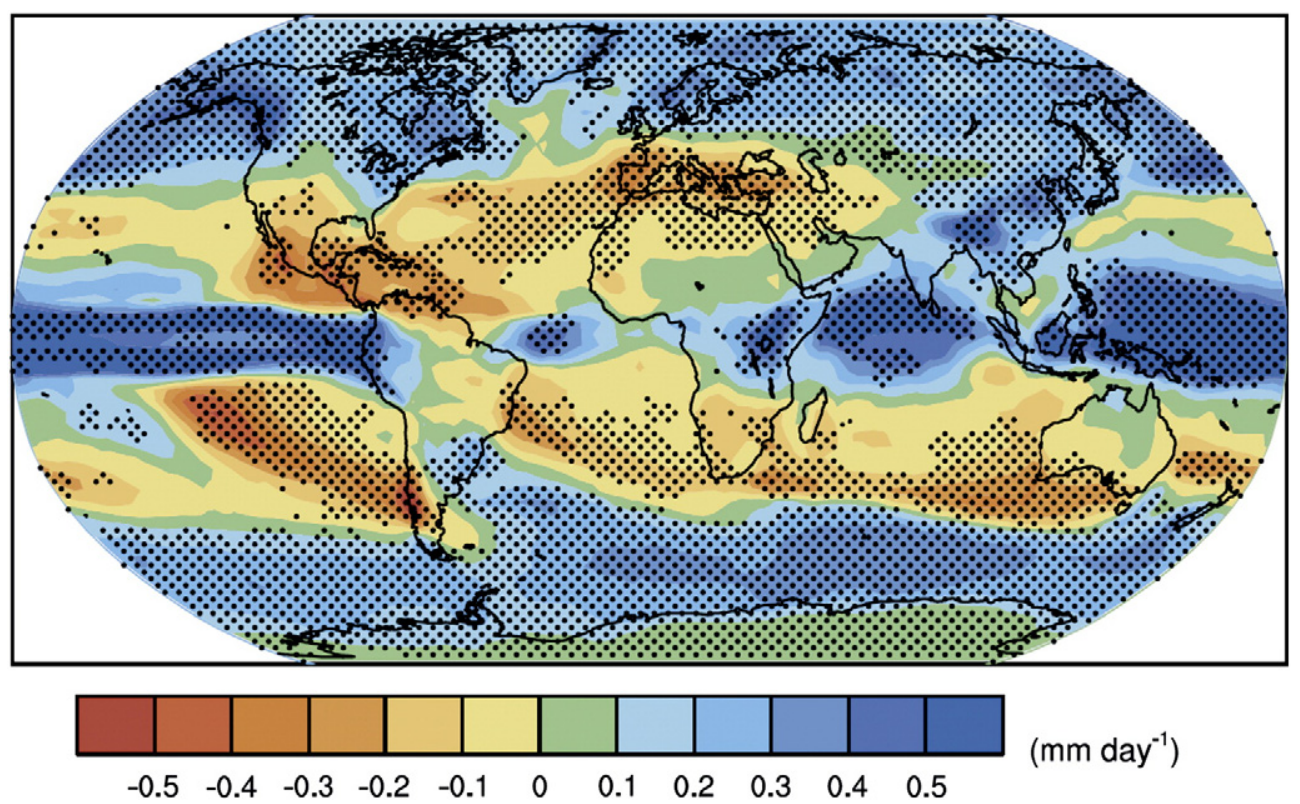

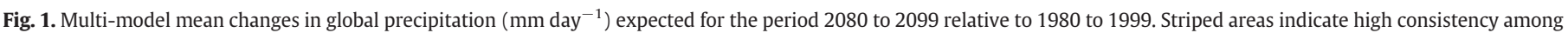
model predictions (Meehl et al., 2007).

First evidence for a significant meridional climatic zonation in the Miocene of Europe comes from analysis of fossil reptile distribution (Böhme, 2003) and Paratethyan molluscs assemblages (Harzhauser et al., 2003), both indicating gradients in mean annual temperature, respective sea surface temperature. A strong meridional precipitation gradient during the Miocene Climatic Optimum was suggested by Böhme (2004) based on the palaeogeography of snakehead fish distribution, with elevated (summer-) precipitation north of the alpine orogen. These ideas have been supported by pollen records (Jiménez-Moreno and Suc, 2007), which show an increase of subdesertic types towards the south, and by the analysis of the body weight structure in mammalian communities (Costeur and Legendre, 2008), which indicate a change from densely forested environments in the north to open environments in the south. A temporal difference in the strength of this gradient was reported by Böhme et al. (2006), who showed that the precipitation gradient was stronger in the early Middle Miocene than in the early Late Miocene (but see Bruch et al., 2007 for low gradients during both intervals). In contrast, Fauquette et al. (2006) found, based on pollen spectra of selected time slices, that the European latitudinal precipitation gradient was higher than today and unchanged from the Middle Miocene until the Middle Pliocene.

However, a shortcoming of previous investigations is the poor time-resolution of analyzed samples or localities, the short timeperiods analyzed, and the lack of a highly resolved temporal correlation between the northern and southern samples. Especially since precipitation can show high temporal variability, such requirements are of crucial importance. Furthermore, the analysis of long and high-resolved precipitation time-series from northern and southern Europe will allow us to investigate the temporal evolution of the precipitation gradient in response to the global climate evolution.

Here we present an analysis of 206 palaeoprecipitation data sets from two twelve million year long proxy records of precipitation for Southwest (Calatayud-Teruel basin) and Central and Eastern Europe (Western and Central Paratethys), covering the late Early and Middle to Late Miocene (17.8-5.3 Ma) at a temporal resolution of about $80 \mathrm{kyr}$ and $200 \mathrm{kyr}$ respectively. The estimates of precipitation are based on the ecophysiological structure of herpetological assemblages (amphibians and reptiles; Böhme et al., 2006).

\section{Materials and methods}

\subsection{Stratigraphic framework}

\subsubsection{Southwest Europe}

The fossil record of amphibian and reptilian communities comes from two continental sequences of NE Spain (Calatayud-Daroca and Teruel basin), both representing endorheic basins. Fossils were found in alluvial and lacustrine facies of the basin margins which may laterally grade into evaporites. The stratigraphic-chronologic framework of 70 fossil-bearing horizons from the younger part of this record (<13 Ma) is already discussed in Böhme et al. (2008).

From older stratigraphic levels 68 new fossil-bearing horizons from the Calatayud-Daroca basin were sampled from an area of few square kilometres east of the Villafeliche village, (see Fig. 2 in Daams et al., 1999a). The sampled section comprises about $320 \mathrm{~m}$ sediments of alluvial and lacustrine origin (Daams et al., 1999a: Figs. 4, 5).

The age model for the total 138 horizons (localities) is according to the one established by Van Dam et al. (2006), which is based on correlation to local magnetostratigraphically dated sections, cycloand lithostratigraphic extrapolation, and biostratigraphic correlation. For details see Van Dam et al. (2006). The fossil amphibians and reptiles we used for the estimation of paleoprecipitation were picked out from exactly the same sediment samples from which Van Dam et al. (2006) derived their small mammal record.

\subsubsection{Central and Eastern Europe}

The fossil record of amphibian and reptilian communities was obtained from several locations of the Paratethys region (Western Paratethys: North Alpine Foreland Basin, Central Paratethys: Styrian, Vienna, Pannonian, Transylvanian Basins, Eastern Paratethys region, see Fig. 2 for sampling sites and Supplementary Table 1 for additional information). The sites contributing to the Paratethys precipitation record range from $46.5^{\circ} \mathrm{N}$ to $49.5^{\circ} \mathrm{N}$ in latitude and $8^{\circ} \mathrm{E}$ (Switzerland) to $28^{\circ} \mathrm{E}$ (Moldova) in longitude; a single locality is from $40^{\circ} \mathrm{E}$ (Southern Russia). The stratigraphic-chronologic framework of 29 fossil-bearing horizons from the younger part of this record (<13 Ma) is already discussed in Böhme et al. (2008).

New data from the older part (17.8 to $12.35 \mathrm{Ma}$ ) is coming from 39 fossil-bearing horizons of the North Alpine Foreland Basin. Fossils 


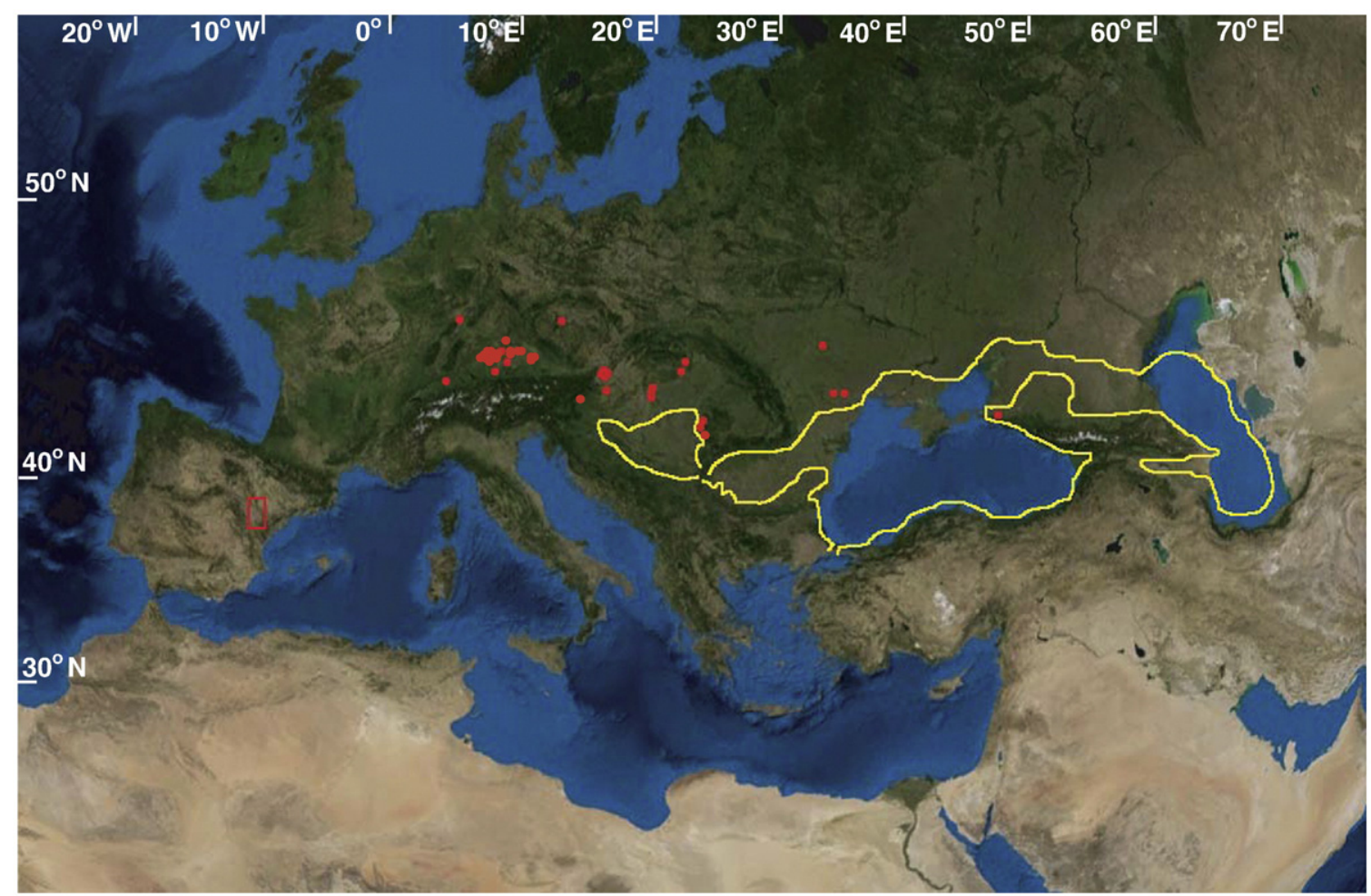

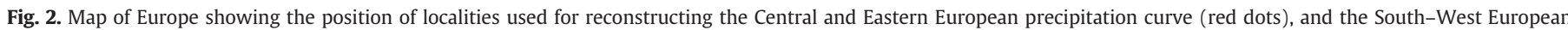
precipitation curve (red rectangular; Calatayud-Teruel Basin). (modified after Böhme et al., 2008).

derived from a variety of depositional and environmental regimes, like near shore, fluvial, lacustrine and swamp facies and karstic fissure fillings (Supplementary Table 1).

The stratigraphic-chronologic framework for the 68 localities is based on correlation to local magnetostratigraphically dated sections, sequence- and lithostratigraphic extrapolation, and biostratigraphic correlation (Böhme et al., 2008). This age-model is not as stable as that for the southwest European record, because many age-determinations rely on the ages of Paratethyan stage boundaries. These however, can change significantly (e.g. the Badenian-Sarmatian boundary in Lirer et al., 2009) and chronologic dating is still in progress for other Central- and Eastern Paratethyan stage boundaries. These uncertainties will clearly influence the temporal resolution of our record.

\subsection{Database for precipitation estimates and published palaeoprecipitation data}

For providing the database for precipitation estimation from herpetofaunal assemblages we used the method described in Böhme et al. (2006), which is also discussed in Böhme et al., 2008. Principally, the method is based on the observation that climate and especially precipitation serves as a direct predictor for the herpetofaunal distribution and species richness and yields robust and widely applicable modelling results (Austin, 2002; Guisan and Hofer, 2003; Girardello et al., 2010). According to their ecophysiological strategies and adaptations to maintain thermoregulation, water balance and gas exchange, amphibians and reptiles (excluding non-fossorial snakes) are assorted into six ecophysiologic groups. The relative frequencies of these groups show in recent communities a highly significant correlation to the mean annual precipitation, with mean prediction errors between 250 and $275 \mathrm{~mm}$ (for further details see Böhme et al., 2006,2008 ). The application of this palaeoprecipitation tool to fossil assemblages with rich amphibian and reptile records (low taphono- mical bias with respect to herpetofauna) from alluvial sediments, paleosoils, caves, fissure fillings, pond and swamp deposits, and channel-fill sediments, expand significantly the spectrum of palaeoenvironments from which precipitation data can be obtained.

For the present investigation we established the database from the Calatayud-Daroca basin following the methodology described in Böhme et al. (2008), i.e. using a range-through approach (Barry et al., 2002; Van Der Meulen et al., 2005) to estimate the ranges of taxa by closing all gaps shorter than 500 kyr (cf. grey cells in Supplementary Table 2). We apply this method consequently on the Southwest European record, because of the spatially small-scale sampling area (see Section 2.1.1.) and the assumption of a single taphonomic mode bias of the assemblages (Van Der Meulen et al., 2005). Because of the larger sampling area and the different depositional regimes in the Central and Eastern Europe dataset we used the range-through approach only in adequate cases (e.g. Hammerschmiede section, Richardhof section in Böhme et al., 2008: Supplementary Information).

The resulting data sets (Supplementary Tables 2 and 3A-C) are converted into absolute annual palaeoprecipitation estimates using Eq. (6) in Böhme et al. (2006). From the absolute precipitation estimates (Fig. 3A) we calculated the precipitation relative to the present-day values (Fig. 3B) on the basis of actual mean precipitation values from the spatially nearest available climate station of a given fossil locality (Supplementary Table 3D). For the Calatayud-Teruel Basin record we choose the stations of Teruel (Mean Annual Precipitation $373 \mathrm{~mm}$ ) and Zaragoza (MAP $318 \mathrm{~mm}$ ) and appreciate a present-day MAP of $350 \mathrm{~mm}$ (Supplementary Table 2).

A part of palaeoprecipitation data analyzed in this paper has been already published by Böhme et al. (2008). These data are 70 data points from the Calaytayud-Daroca and the Teruel basins, time interval 13.56 to $5.36 \mathrm{Ma}$ (Böhme et al., 2008: Supplementary Table 2A-C), and 29 data points from the Paratethys area, time interval 13.27 to $5.75 \mathrm{Ma}$ (Böhme et al., 2008: Supplementary Table 3A). One data point is published by Venczel and Ştiucă (2008). 


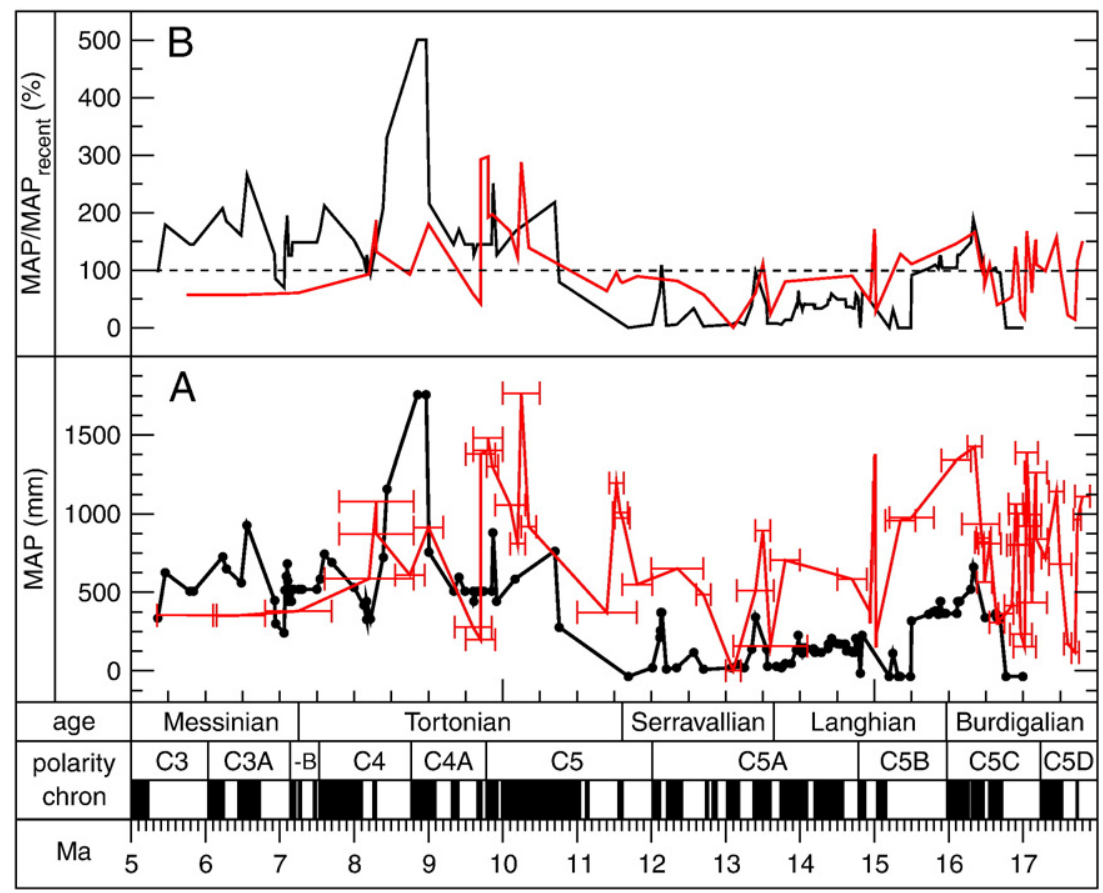

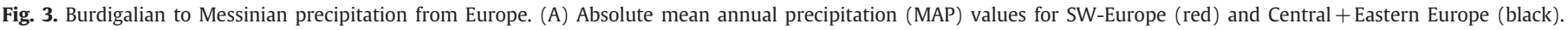
(B) Ratio of MAP relative to recent; $100 \%$ means no change relative to recent (dotted line).

68 data points from the Calatayud-Daroca basin (time interval 17.02 to $13.68 \mathrm{Ma}$ ) and 38 data points from the North Alpine Foreland Basin, time interval 17.8 to $13.2 \mathrm{Ma}$ are new and are published in the present paper (Supplementary Tables 2 and 3).

The error bars given are in terms of absolute ages of the fossil localities. Absolute age control is better for some localities than for others due to different dating methods (see Supplementary Table 1). However, the chronological order of the localities has been well established and is independent of the absolute error bars. Therefore the apparent overlap of the error bars does not affect the chronological order.

\subsection{Data handling}

A comparison between the precipitation time series from Southwest Europe and Central and Eastern Europe requires a common age model, which however is not the case here. We first have to treat the absolute age uncertainties of the data points from the Paratethys area before we can fit a model function to them, which then can easily interpolated at the points specified by the good age model for the data from south-western Europe. The stochastic ('Boolean') approach to treat the age uncertainties of the data from Central and Eastern Europe (see details in Böhme et al., 2008: online supplement) transforms error bars in the age model into error bars in precipitation (Fig. 4). After this transformation, the precipitation gradient between Southwest Europe and Central and Eastern Europe can be calculated by the subtraction of the two resulting precipitation curves (Fig. 5).

\section{Results}

The results show that precipitation in both regions has large amplitudes during the Miocene, ranging from near 0 to over $1700 \mathrm{~mm}$ per year (Fig. 3). Very humid intervals are present especially in Central Europe during the Langhian and during the Tortonian and in south-western Europe shortly after $9 \mathrm{Ma}$ in the late Tortonian. Very dry intervals occur in both regions between the Langhian and
Tortonian (late Langhian to earliest Tortonian) and in the early Messinian of Central and Eastern Europe.

At a larger scale the temporal precipitation trends are well comparable between 16 and $8 \mathrm{Ma}$ (Figs. 3B, 5). During periods which are generally wetter than present (Langhian, Tortonian) precipitation reaches 200 to over $400 \%$ of present-day values (Fig. 3B), which means locally 300 to over $1.000 \mathrm{~mm}$ more rainfall per year (Fig. 5). During drier climate rainfall is significantly reduced and single areas receive up to 300 to $500 \mathrm{~mm}$ less precipitation compared to today. After $8 \mathrm{Ma}$ (late Tortonian, early Messinian) precipitation trends diverge, showing southwest Europe more humid than today, whereas Central and Eastern Europe is much drier.

The present-day precipitation gradient between the studied regions is about $400 \mathrm{~mm} / \mathrm{a}(\sim 1.1 \mathrm{~mm} /$ day; calculated on the basis of the Spanish reference climate stations Zaragoza and Teruel with

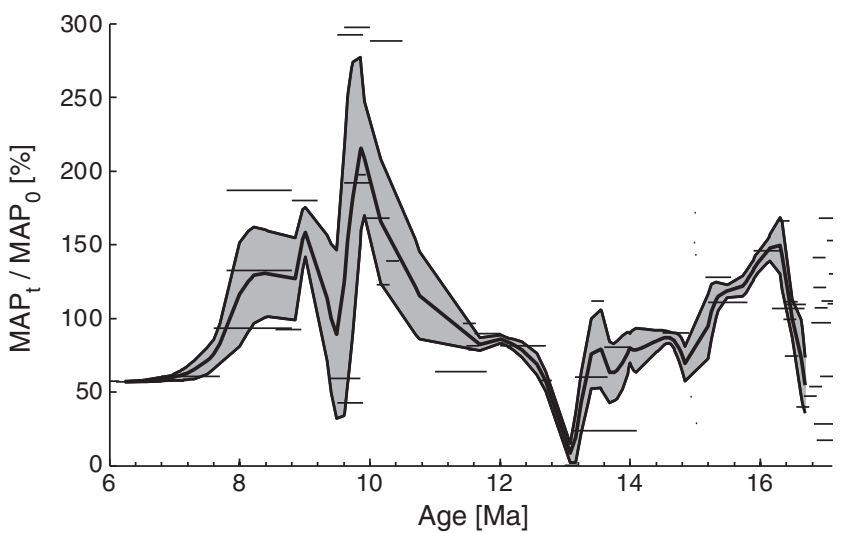

Fig. 4. Ensemble means and $\pm 1 \sigma$ confidence intervals (grey shaded area) of the relative mean annual precipitation, $\mathrm{MAP}_{t} / \mathrm{MAP}_{0}(\times 100 \%)$ for the Paratethys area (Central and Eastern Europe), obtained from averaging over $N=1000$ random age models, each consistent with the given age uncertainties in the original data set (black bars in Fig. 3A). Horizontal black bars represent the raw data with age uncertainties. 


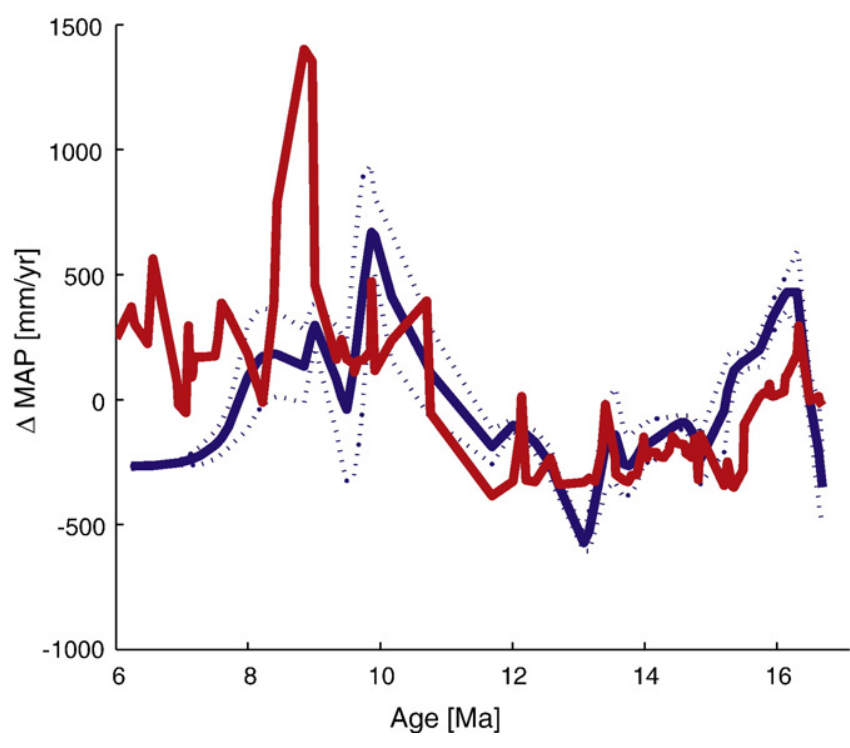

Fig. 5. Mean annual precipitation relative to recent for Southwest Europe (red) and Central and Eastern Europe (blue). Dotted line represents the $\pm 1 \sigma$ confidence interval for the Paratethys record.

$350 \mathrm{~mm} / \mathrm{a}$ and the mean of all Central and Eastern European reference stations used with $750 \mathrm{~mm} / \mathrm{a}$ ). Calculating the Miocene precipitation gradients (Fig. 6) we observe significant changes during the investigated time-span, reaching up to $3 \mathrm{~mm}$ in daily precipitation relative to recent. The large-scale trend is that the gradient decreases during the Miocene, being about $1 \mathrm{~mm} /$ day stronger during the Langhian and up to $3 \mathrm{~mm}$ /day weaker during the late Tortonian and early Messinian, implying that the gradient was temporally reversed during that times (southwest Europe is wetter than Central and Eastern Europe). At a finer scale significant stronger gradients occur also in the late Serravallian ( 12 to $11 \mathrm{Ma}$ ) and during the first washhouse climate interval (Böhme et al., 2008) around 10 Ma in the

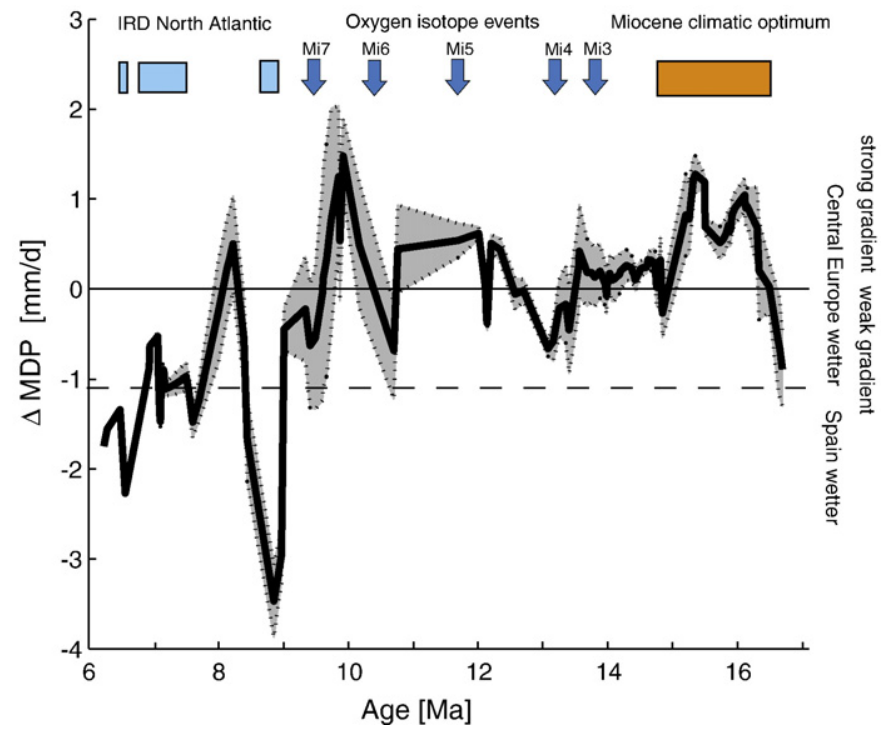

Fig. 6. Gradient in the mean daily precipitation (MDP) relative to recent between Central Europe and Southern Europe for the Miocene, with \pm 1 sigma error bars, indicated by the stippled lines enclosing the grey area. A positive gradient means that Central Europe receives more precipitation than Spain relative to recent. Main Miocene climatic events are shown: Miocene climatic optimum (orange bar; stage I of Holbourn et al., 2007), oxygen isotope events (arrows; Westerhold et al., 2005), and intensification of the Northern Hemisphere Glaciation as indicated by North Atlantic ice-rafted debris from the Fram Strait (blue bars; Winkler et al., 2002) and Irminger Basin (St. John and Krissek, 2002). early Tortonian. Reduced gradients are further present in the latest Burdigalian (16.5 to $16 \mathrm{Ma}$ ), the early Serravallian (13.6 to $12.7 \mathrm{Ma}$ ), the late Serravallian (around $12 \mathrm{Ma}$ ) and the earliest Tortonian (around $10.5 \mathrm{Ma}$ ). Periods with inversed precipitation gradient are the second washhouse climate interval (Böhme et al., 2008) during the middle Tortonian ( 9 to $8.5 \mathrm{Ma}$ ) and the early Messinian (6.8 to $6 \mathrm{Ma})$.

\section{Discussion}

The Miocene Climatic Optimum was the warmest period during the Neogene (Zachos et al., 2001) with minimum ice-volume and eccentricity-paced climate until 14.7 Ma (Holbourn et al., 2007). According to numerical simulation of You et al. (2009), the global annual mean surface temperature at around 15 Ma were about $3{ }^{\circ} \mathrm{C}$ higher than today, and the meridional temperature gradient on the northern hemisphere was less pronounced than present. Indeed, European mid-latitudes proxy-data for that time indicate 9 to $12{ }^{\circ} \mathrm{C}$ warmer temperatures in the annual mean than today (Böhme, 2003; Mosbrugger et al., 2005; Ivanov and Böhme, in press). Our reconstructed latitudinal precipitation gradient (Fig. 6) is strongly increased during this period of global warmth, supporting previous results (Böhme, 2004; Böhme et al., 2006; Jiménez-Moreno and Suc, 2007; Costeur and Legendre, 2008). Between $15 \mathrm{Ma}$ and $14 \mathrm{Ma}$, the gradient is comparable to present-day values. However, the absolute precipitation values in both regions are significantly lower than today and remain so until about $10.5 \mathrm{Ma}$, which is also supported by the coeval occurrence of evaporites in the Spanish basins (Sanz-Rubio et al., 2003), but stands in contradiction with plant proxy data showing wetter than present conditions in Central and Eastern Europe during the Serravallian (see Bruch et al., 2011). Discrepancies to botanical data can partly be explained due to problems reconstructing dry climates with botanical methods (Böhme et al., 2006, 2007; Bruch et al., 2011), inaccurate dating of plant-bearing localities, but also insufficient herpetological data from the Serravallian of Central Europe (some new Central European localities from the early Seravallian indicate very wet conditions, however the chronology of these localities is still poorly constrained).

We interpret the change from strong gradient to normal gradient (at about $15 \mathrm{Ma}$ ) and the onset of low absolute precipitation values as a result of the initiation of global cooling associated with obliquity modulation of climate (Holbourn et al., 2007). Continental proxy-data show no significant cooling at that time (Böhme et al., 2007), implying that surface temperature changes are beyond the resolution of the methods. The massive and stepwise global cooling between 14 and $13 \mathrm{Ma}$ (Mi3 and Mi4 isotope event at 13.8 and $13.2 \mathrm{Ma}$, Shevenell et al., 2004; Westerhold et al., 2005; Holbourn et al., 2007) is however well documented in terrestrial ecosystems and proxy-data indicates for Central Europe a drop in mean annual temperatures between 3 and $5{ }^{\circ} \mathrm{C}$ (relative to the climate optimum; Böhme, 2003; Mosbrugger et al., 2005; Uhl et al., 2006). The latitudinal precipitation gradient responds to this cooling with a strong decrease to levels about $0.5 \mathrm{~mm}$ /day lower than today (Fig. 6).

Palaeobotanical proxy-data indicate no significant changes in the Central European mean annual temperatures from the Serravallian until the Messinian, with values ranging between 14 and $16{ }^{\circ} \mathrm{C}$ similar to the early Serravallian (e.g. Mosbrugger et al., 2005; Erdei et al., 2007). However, our precipitation gradient shows an analogue correspondence between increased ice-sheet growth and reduced precipitation gradient, as for the Miocene major cooling (Mi3, Mi4), also for isotope events Mi6 (10.4 Ma) and Mi7 (9.45 Ma), whereas a possible correlation with Mi5 (11.7 Ma; all isotope-event ages according to Westerhold et al., 2005) is obscured because of the scarcity of available proxy-data and pure age-control (Fig. 3) around the Serravallian-Tortonian boundary. 
The significant increase in the precipitation gradient to levels comparable to or even larger than the Miocene Climatic Optimum occur around $10 \mathrm{Ma}$ and coincide with the first washhouse-climate period of Böhme et al. (2008). This pronounced increase in gradient is due to strongly amplified precipitation in central Europe (see Fig. 3A). From about $9 \mathrm{Ma}$ onward, the gradient decreases sharply and remains weaker than today. During two periods, the gradient is below $-1.1 \mathrm{~mm} / \mathrm{d}$, which means that Spain is wetter than Central Europe (see dashed line in Fig. 6). The first period corresponds to the second washhouse-climate phase, during which the absolute precipitation values in Spain are significantly higher than in Central Europe (Fig. 3A), as they are in the second period (Early Messinian). This Early Messinian reversed precipitation gradient is of special interest because it occurs during two periods of sea-level lowering in the Eastern Paratethys; the late Maeotian ( $>6 \mathrm{Ma}$ ) and the Portaferrian (5.8 to $5.5 \mathrm{Ma}$; Krijgsman et al. 2010). The low absolute rainfall values in the Paratethys area may indicate that potential evapotranspiration significantly exceeded the precipitation, which supports the hypothesis of a negative hydrologic balance in the Paratethys during the Early Messinian by Krijgsman et al., 2010.

The decreasing tendency of the gradient towards the end of the Miocene may be ascribed to further global cooling, especially on the Northern Hemisphere, with more widespread continental ice-sheets, as indicated by ice-rafted debris in the Fram Strait (Winkler et al., 2002) and Irminger Basin (St. John and Krissek, 2002) and by increasing $\delta \mathrm{O}^{18}$ in the North Atlantic (Hodell et al., 2001). These observations suggest a more pronounced latitudinal temperature gradient on the Northern Hemisphere, so that the gradient in precipitation may reflect a response to the temperature gradient

Our reconstructed gradient curve (Fig. 6) shows no direct correlation with the global temperature signal from marine oxygen isotopes constructed by Zachos et al. (2001), which implies a non-linear regional response of European precipitation to global temperature variations. This interesting observation suggests that the regional atmospheric circulation is primarily influenced by factors other than global temperature, such as global geography, ice-volume, distribution and types of vegetation, hemispherical temperature gradient, as well as local and regional topography.

High amplitude shifts in precipitation gradients should have a pronounced impact on latitudinal distribution of ecosystems associated with regional faunal migration, origination and extinction events (turnover events). This is especially true for strong decrease of the gradient from positive to negative values (i.e. from strong gradient to no or reversed gradient), when the humidity zonation of the western part of Europe (nearly) disappeared. Such fluctuations are found in particular during the Late Miocene starting around 10.7 Ma, 9.7 Ma and $9 \mathrm{Ma}$, but also between 14 and $13 \mathrm{Ma}$ (Fig. 6). These ages are remarkably coinciding with major migration and turnover events in the Iberian Peninsula, corresponding to the middle-to-late Aragonian turnover ( 13.7 Ma; Daams et al., 1999b; van der Meulen et al., 2005), the Hippotherium immigration (10.8-10.7 Ma in Central Spain: Garcés et al., 2003), the early Vallesian mammal turnover (10.4 Ma), the midVallesian crisis (9.7 Ma), and the latest Vallesian bioevents (9.2 to 8.8 Ma; all Vallesian ages according to Agusti et al., 1999). Although we acknowledge that every single faunal turnover or migration event is associated with distinct palaeobiologic, palaeogeographic and palaeoclimatic circumstances, the shifting pattern of the precipitation gradient is obviously a major factor for biotic events across Europe.

\section{Conclusions}

Overall, our data suggest that the latitudinal precipitation gradient in Europe from the Middle to Late Miocene were highly variable, with a general tendency towards a reduced gradient relative to present day values. Changes in the gradient can be interpreted in terms of global changes in the climate system, with a positive correlation between changes in temperature and changes in gradient, i.e., the gradient decreases during cooling periods and increases during warming periods, similar to results from simulations of future climate change. However, our data also indicate that the European precipitation gradient responds non-linearly to the global temperature signal, implying that the regional intensity of precipitation is controlled by other global and regional factors too. Finally, our results suggest that major fluctuations in the precipitation gradient can be responsible for shifts in ecosystem distribution, and particularly, for faunal turnover in South Western Europe.

\section{Acknowledgement}

The first author thanks the German Science Foundation (DFG) for financial support (grant number BO 1550/8).

\section{Appendix A. Supplementary data}

Supplementary data to this article can be found online at doi:10.1016/j.palaeo.2010.09.028.

\section{References}

Agusti, J., Cabrera, L., Garcés, M., Llenas, M., 1999. Mammal turnover and global climate change in the late Miocene terrestrial record of the Valles-Penedès basin (NE Spain). In: Agusti, J., Rook, L., Andrews, P. (Eds.), The evolution of Neogene terrestrial ecosystems in Europe. Cambridge University Press, Cambridge, pp. 397-412.

Austin, M.P., 2002. Spatial prediction of species distribution: an interface between ecological theory and statistical modelling. Ecological Modelling 157, 101-118.

Barry, J.C., Morgan, M.E., Flynn, L.J., Pilbeam, D., Behrensmeyer, A.K., Mahmood, A.S, Khan, I.A., Badgley, C., Hicks, J.J.K., 2002. Faunal and environmental change in the late Miocene Siwaliks of northern Pakistan. Palaeobiology Memoirs (suppl.) 3, $1-71$.

Böhme, M., 2003. Miocene climatic optimum: evidence from lower vertebrates of central Europe. Palaeogeography, Palaeoclimatology, Palaeoecology 195, 389-401.

Böhme, M., 2004. Migration history of air-breathing fishes reveal Neogene atmospheric circulation pattern. Geology 32, 393-396.

Böhme, M., Ilg, A., Ossig, A., Küchenhoff, H., 2006. A new method to estimate paleoprecipitation using fossil amphibians and reptiles and the Middle and Late Miocene precipitation gradients in Europe. Geology 34, 425-428.

Böhme, M., Bruch, A., Selmeier, A., 2007. The reconstruction of the Early and Middle Miocene climate and vegetation in the North Alpine Foreland Basin as determined from the fossil wood flora. Palaeogeography, Palaeoclimatology, Palaeoecology 253, 91-114.

Böhme, M., Ilg, A., Winklhofer, M., 2008. Late Miocene “washhouse" climate in Europe. Earth and Planetary Science Letters 275, 393-401.

Bruch, A.A., Uhl, D., Mosbrugger, V., 2007. Miocene climate in Europe - patterns and evolution: a first synthesis of NECLIME. Palaeogeography Palaeoclimatology Palaeoecology 253, 1-7.

Bruch, A.A., Utescher, T., Mosbrugger, V., 2011. Precipitation patterns in the Miocene of Central Europe and the development of continentality. Palaeogeography Palaeoclimatology Palaeoecology 304, 202-211 (this volume)

Christensen, J.H., Hewitson, B., et al., 2007. Regional Climate Projections. In: Solomon, S., Qin, D., Manning, M., et al. (Eds.), Climate Change 2007: The Physical Science Basis. Contribution of Working Group I to the Fourth Assessment Report of the Intergovernmental Panel on Climate Change. Cambridge University Press, Cambridge.

Costeur, L., Legendre, S., 2008. Mammalian communities document a latitudinal environmental gradient during the Miocene climatic optimum in Western Europe. Palaios 23, 280-288.

Daams, R., van der Meulen, A., Alvarez Sierra, M.A., Peláez-Campomanes, P., Krijgsman, W., 1999a. Aragonian stratigraphy reconsidered, and a re-evaluation of the middle Miocene mammal biochronology in Europe. Earth and Planetary Science Letters $165,287-294$.

Daams, R., van der Meulen, A., Pelaez-Campomanes, P., Alvarez-Sierra, A., 1999b. Trends in rodent assemblages from the Aragonian (early-middle Miocene) of the Calatayud-Daroca Basin. In: Agusti, J., Rook, L., Andrews, P. (Eds.), The evolution of Neogene terrestrial ecosystems in Europe. Cambridge University Press, Cambridge, pp. 127-139.

Douville, H., Chauvin, F., Planton, S., Royer, J.-F., Salas-Mélia, D., Tyteca, S., 2002. Sensitivity of the hydrological cycle to increasing amounts of greenhouse gases and aerosols. Climate Dynamics 20, 45-68.

Erdei, B., Hably, L., Kázmér, M., Utescher, T., Bruch, A.A., 2007. Neogene flora and vegetation development in the Pannonian Basin - relations to palaeoclimate and palaeogeography. Palaeogeography Palaeoclimatology Palaeoecology 253, $115-140$

Fauquette, S., Suc, J.-P., Jiménez-Moreno, G., Favre, E., Jost, A., Micheels, A., 2006. Latitudinal climatic gradients in the Western European and Mediterranean regions from the Mid-Miocene (c. $15 \mathrm{Ma}$ ) to the Mid-Pliocene (c. $3.5 \mathrm{Ma}$ ) as quantified from pollen data. Geophysical Research Abstracts 8, 07340. 
Garcés, M., Krijgsman, W., Pelaez-Campomanes, P., Alvarez-Sierra, A.M., Daams, R. 2003. Hipparion dispersal in Europe: magnetostratigraphic constraints from the Daroca area: Coloquios de Paleontologia, special volume 1, pp. 171-178.

Girardello, M., Griggio, M., Whittingham, M.J., Rushton, S.P., 2010. Models of climate associations and distributions of amphibians in Italy. Ecological Research 25, $103-111$.

Guisan, A., Hofer, U., 2003. Predicting reptile distributions at the mesoscale: relation to climate and topography. Journal of Biogeography 30, 1233-1243.

Harzhauser, M., Mandic, O., Zuschin, M., 2003. Changes in Paratethyan marine molluscs at the Early/Middle Miocene transition - diversity, paleogeography and paleoclimate. Acta Geologica Polonica 53, 323-339.

Hodell, D.A., Curtis, J.H., Sierro, F.J., Raymo, M.E., 2001. Correlation of late Miocene to early Pliocene sequences between the Mediterranean and North Atlantic. Paleoceanography 16, 2164-2178.

Holbourn, A.E., Kuhnt, W., Schulz, M., Flores, J.A., Andersen, N., 2007. Orbitally-paced climate evolution during the middle Miocene "Monterey" carbon-isotope excursion. Earth and Planetary Science Letters 261, 534-550.

Ivanov, M., Böhme, M., in press. Snakes from Griesbeckerzell (Langhian, Early Badenian), North Alpine Foreland Basin (Germany), with comments on the evolution of snake faunas in central Europe during the Miocene Climatic Optimum. Geodiversitas.

Jiménez-Moreno, G., Suc, J.-P., 2007. Middle Miocene latitudinal climatic gradient in Western Europe: evidence from pollen records. Palaeogeography, Palaeoclimatology, Palaeoecology 253, 208-225.

Krijgsman, W., Stoica, M., Vasiliev, I., Popov, V.V., 2010. Rise and fall of the Paratethyan Sea during the Messinian Salinity Crisis. Earth and Planetary Science Letters 290, 183-191.

Lirer, F., Harzhauser, M., Pelosi, N., Piller, W.E., Schmid, H.P., Sprovieri, M., 2009. Astronomically forced teleconnection between Paratethyan and Mediterranean sediments during the Middle and Late Miocene. Palaeogeography, Palaeoclimatology, Palaeoecology 275, 1-13.

Meehl, G.A., Stocker, T.F., et al., 2007. Global Climate Projections. In: Solomon, S., Qin, D., Manning, M., et al. (Eds.), Climate Change 2007: The Physical Science Basis. Contribution of Working Group I to the Fourth Assessment Report of the Intergovernmental Panel on Climate Change. Cambridge University Press, Cambridge.
Mosbrugger, V., Utescher, T., Dilcher, D.L., 2005. Cenozoic continental climatic evolution of Central Europe. Proceedings of the National Academy of Science 102, 14964-14969.

Rowell, D.P., Jones, R.G., 2006. Causes and uncertainty of future summer drying over Europe. Climate Dynamics 27, 281-299.

Sanz-Rubio, E., Sánchez-Moral, S., Can averas, J.C., Abdul-Aziz, H., Calvo, J.P., Cuezva, S Mazo, A.V., Rouchy, J.M., Sesé, C., van Dam, J., 2003. Sintesis de la chronoestratigrafia y evolucion sedimentaria de los sistemas lacustres evaporiticos y carbonatados neogenos de la Cuenca de Calatayud-Montalban. Estudios Geologicos 59, 83-105.

Shevenell, A.E., Kennett, J.P., Lea, D.W., 2004. Middle Miocene Southern Ocean Cooling and Antarctic Cryosphere Expansion. Science 305, 1766-1770.

St. John, K.E.K., Krissek, L.A., 2002. The late Miocene to Pleistocene ice-rafting history of southeast Greenland. Boreas 31, 28-35.

Uhl, D., Bruch, A.A., Traiser, Ch., Klotz, S., 2006. Palaeoclimate estimates for the Middle Miocene Schrotzburg flora (S-Germany) - a multi-method approach. International Journal of Earth Sciences 95, 1071-1085.

Van Dam, J.A., Abdul Aziz, H., Álvarez Sierra, M.A., Hilgen, F.J., Van Den Hoek Ostende, L.W. Lourens, L.J., Mein, P., Van Der Meulen, A.J., Pelaez-Campomanes, P., 2006. Long-period astronomical forcing of mammal turnover. Nature 443, 687-691.

Van Der Meulen, A.J., Pelaez-Campomanes, P., Levin, S.A., 2005. Age structure, residents, and transients of Miocene rodent communities. The American Naturalist 165, 108-125.

Venczel, M., Stiucă, E., 2008. Late middle Miocene amphibians and squamate reptiles from Taut, Romania. Geodiversitas 30, 731-763.

Westerhold, T., Bickert, T., Röhl, U., 2005. Middle to late Miocene oxygen isotope stratigraphy of ODP site 1085 (SE Atlantic): new constrains on Miocene climate variability and sea-level fluctuations.- Palaeogeography, Palaeoclimatology. Palaeoecology 217, 205-222.

Winkler, A., Wolf-Welling, T.C.W., Stattegger, K., Thiede, J., 2002. Clay mineral sedimentation in high northern latitude deep-sea basins since the Middle Miocene (ODP Leg 151, NAAG). International Journal of Earth Sciences 91, 133-148.

You, Y., Huber, M., Müller, R.D., Poulsen, C.J., Ribbe, J., 2009. Simulation of the Middle Miocene climate optimum. Geophysical Research Letters 36, L04702. doi:10.1029/ 2008GL036571.

Zachos, J., Pagani, M., Sloan, L., Thomas, E., Billups, K., 2001. Trends, rhythms, and aberrations in global climate 65 Ma to present. Science 292, 686-693. 